Association for Information Systems

AIS Electronic Library (AISeL)

\title{
Digital Credentials in Higher Education Institutions: A Literature Review
}

\author{
Elena Wolz \\ Technical University of Munich, IT Service Center (ITSZ), Munich, Germany \\ Matthias Gottlieb \\ Technical University of Munich, IT Service Center (ITSZ), Munich, Germany \\ Hans Pongratz \\ Technical University of Munich, IT Service Center (ITSZ), Munich, Germany
}

Follow this and additional works at: https://aisel.aisnet.org/wi2021

Wolz, Elena; Gottlieb, Matthias; and Pongratz, Hans, "Digital Credentials in Higher Education Institutions: A Literature Review" (2021). Wirtschaftsinformatik 2021 Proceedings. 5.

https://aisel.aisnet.org/wi2021/KDigitalEducation15/Track15/5

This material is brought to you by the Wirtschaftsinformatik at AIS Electronic Library (AISeL). It has been accepted for inclusion in Wirtschaftsinformatik 2021 Proceedings by an authorized administrator of AIS Electronic Library (AISeL). For more information, please contact elibrary@aisnet.org. 


\title{
Digital Credentials in Higher Education Institutions: A Literature Review
}

\author{
Elena Wolz ${ }^{1}$, Matthias Gottlieb ${ }^{1}$, Hans Pongratz ${ }^{1}$ \\ ${ }^{1}$ Technical University of Munich, IT Service Center (ITSZ), Munich, Germany \\ \{elena.wolz,matthias.gottlieb,pongratz\}@tum.de
}

\begin{abstract}
Digitalization is an essential driver for change, also influencing universities in their operation. However, the graduation certificate is still paperbased and does not fit employers' digitized recruitment processes. Digitizing the graduation certificate is overdue to align with the digitized processes of employers and universities. However, there is only a few research on that issue. This paper aims to conduct a systematic literature analysis. Therefore, we investigated 147 articles in the context of research on digital credentials. The results show that, although there is an increasing interest in this research area, the research community lacks a unique understanding of digital credentials. The paper gives an overview of research made so far and contributes to identifying research gaps in the context of digital credentials.
\end{abstract}

Keywords: Digital credentials, digital badges, higher education institutions

\section{Introduction}

Digitalization is changing almost every area of life. Also, it affects universities in their role as a teaching and researching organization [1]. Universities use new technologies to modify their processes; for example, developing simulated learning environments via virtual reality [2], video archives of lectures, and massive open online courses (MOOC) supporting the student's ability to learn independently regarding time and place [1]. The corona pandemic pushed the digitalization of education further. However, graduation certificates issued by German higher education institutions (HEI) are still paper-based leading to several inefficiencies. The paper-based graduation certificate does not fit the most digitized recruitment processes of employers, leading to the certificate owner's expenditures to digitalize the certificate, so automated processing of the contents is not possible by employers. Besides, the employer has to struggle with trust issues, as it is easy to falsify paper-based graduation certificates. Digitizing the graduation certificate could increase efficiency and is overdue to align with the digitized recruitment processes.

Digital credentials are "the digital equivalent of paper documents, plastic tokens, and other tangible objects issued by trusted parties" [3]. Additionally, for data protection and privacy, they provide the possibility to hide certain information for the accessing recipient [3]. We have two main reasons to analyze digital credentials in detail. First, using digital credentials for digitizing graduation certificates could solve the caused issues of paper-based certificates such as data protection and time for authentication 
and validation. Second, digital credentials in the context of HEIs are relatively new and little-discussed yet [4]. In addition to that, prior research lacks an overview of that research field, building the basis for further studies. The article provides a basis for further research on digital credentials in higher education. Thus, we follow the research question: What is the current state of the art of research on digital credentials in the context of higher education institutions?

The paper conducts a systematic literature review analyzing 147 papers in the context of digital credentials in higher education institutions. It contributes to evaluating the relevance of digital credentials as a research area in the context of higher education, the creation of a status quo of research in that field, and the identification of research gaps.

We structure the study as follows: In the section Terms and Related Work, we give a general understanding of digital credentials and their potential in the context of HEIs. Afterward, we describe the methodology approach and present in the section Results our findings. We discuss the findings in the section Discussion. Finally, we give an outlook for future research and state the paper's limitations in the section Conclusion.

\section{Terms and Related Work}

Digital credentials represent "the digital equivalent of paper documents, plastic tokens, and other tangible objects issued by trusted parties" [3]. In education, digital credentials enable the holder to decide which information when and how revealed to others. Additionally, digital credentials provide greater security than paper-based documents [3]. In conclusion, digital credentials can change the way of issuing and managing graduation certificates from paper-based to digitized.

Digital badges emerged in the educational area as another trend [5]. According to [6], a digital badge "is a representation of an accomplishment, interest or affiliation that is visual, available online, and contains metadata including links that help explain the context, meaning, process and result of an activity." Digital badges have their origin in games, where the user gets badges by reaching performance benchmarks. Within education, they tend to motivate learners by providing an incentive to identify the progress in learning and support credential management [6]. Digital badges contain metadata referring to the skills and knowledge earned, like information about the issuer, knowledge achieved, activities are undertaken to achieve the badge, and quality of the experiences and performances [6]. Digital badges are used for certification: formal, non-formal, and in-formal qualifications, but on a very granular level, not yet very widespread.

"Micro-credentials are a virtual, portable way of cashing in on acquired learning, especially granular skills" [7]. They are mini-certifications in study programs and enable students to represent the knowledge achieved through successfully participating in a module or course. To earn these micro-credentials, a student must submit evidence of their learning process, which is evaluated afterward. Employers can use this 
achievement accreditation for evaluating their new hires [8]. Therefore, the focus lies on the content and not the certificate replacement.

Alternative credentials represent learning certifications of non-credit programs and therefore are no digitization of traditional transcripts. These digital credentials describe an individual's skills and knowledge and complement the traditional transcript [9]. As a result, alternative credentials support the concept of lifelong learning.

Technical applications of digital credentials are found in the area of platforms. One application consists of a centralized server platform [10]; other platforms use the blockchain to manage digital credentials [11-15]. Platforms using the open-source Ethereum infrastructure have been implemented $[12,14]$ and solutions with the Bitcoin blockchain as the underlying infrastructure [11].

\section{Methodological Approach}

In order to assess the current state of the art on digital credentials in HEIs, we executed a systematic literature analysis based on [16] and [17]. The search for relevant literature covered the databases: Scopus, EBSCOHost, ACM Digital Library, ScienceDirect, IEEE Explore, and AISeL. To identify appropriate literature, we choose an iterative approach concerning the hit rate. As the goal is to derive the current status of research on digital credentials, we considered 'Digital Credentials' as a relevant keyword for the query in a five-step approach. Also, getting the newest word stem in this specific field [4]. Figure 1 illustrates the applied methodology.

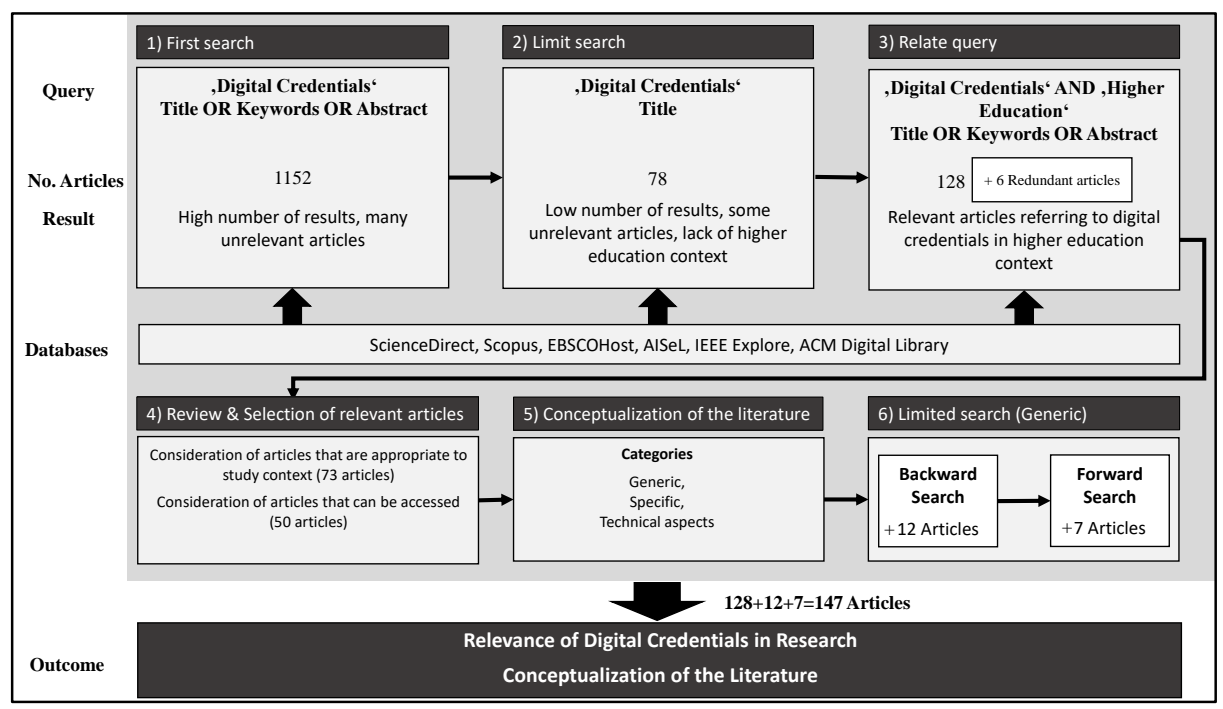

Figure 1: Literature Review Approach

First, we searched for this within title, keywords, and abstract (result: hit rate 1152). 
Second, to enclose the found literature, the keyword was searched only in the titles (result: hit rate 78). However, many of the found paper did not relate to the topic of digital credentials in HEIs. The fact that digital credentials are a general term used in different contexts causes less relevance. [3] defined digital credentials as "the digital equivalent of paper documents, plastic tokens, and other tangible objects issued by trusted parties."

Third, to further specify the query for this paper's research context, it was useful to add the keyword 'Higher Education' to the query. The search for 'Digital Credentials' and 'Higher Education' within title, keywords, and abstract resulted in 128 articles. We reviewed the articles and selected contributions that are relevant to the study. To define relevant articles, we elaborated if the studies are referring to the defined research context, resulting in 73 appropriate contributions. Among these 73 contributions, 23 could not be accessed. As a result, we included studies that could not be accessed in the literature's conceptualization but excluded them from further investigations.

Fourth, we categorized the digital credentials into generic, specific, technical aspects. Moreover, we documented the usage of terms in the context of digital credentials. To gather additional literature, we conducted a forward and backward search focusing on the category digital credentials generic, according to [16]. The forward and backward search revealed 19 additional contributions for investigation. In total, we reviewed 147 articles, whereby we used 73 articles for the conceptualization of the literature and further investigated 69 contributions according to their contents.

\section{$4 \quad$ Results}

We conceptualized 73 studies, and most contributions discuss digital badges (61). The other categories occur with similar frequency: generic (11), alternative credentials (4), micro-credentials (6), and technical application (6). Table 1 presents the identified papers and the number of papers assigned to a specific category.

\begin{tabular}{|c|c|c|c|c|c|}
\hline \multirow[t]{3}{*}{ Author(s) } & \multicolumn{4}{|c|}{$\begin{array}{c}\text { Digital } \\
\text { Credentials }\end{array}$} & \multirow[t]{3}{*}{ 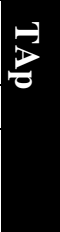 } \\
\hline & \multirow{2}{*}{8} & \multicolumn{3}{|c|}{ Specific } & \\
\hline & & $\underset{ت ્ 0}{ت}$ & ? & $\stackrel{3}{9}$ & \\
\hline AACSB [18], Bull [19] & & & $\mathrm{X}$ & & \\
\hline Matkin [9], Farmer and West [20] & & $\mathrm{X}$ & $\mathrm{X}$ & & \\
\hline Swan [21] & & & & & $\mathrm{X}$ \\
\hline Jirgensons and Kapenieks [22] & & $\mathrm{X}$ & & & $\mathrm{X}$ \\
\hline $\begin{array}{l}\text { Kamišalić, Turkanović, Mrdović and Heričko [23], } \\
\text { Hölbl, Kamisalić, Turkanović, Kompara, Podgorelec and } \\
\text { Herićko [12], Arenas and Fernandez [24], Newswire } \\
\text { [25], Newswire [26] }\end{array}$ & $\mathrm{X}$ & & & & $\mathrm{X}$ \\
\hline Connolly [27] & $\mathrm{X}$ & $\mathrm{X}$ & & & \\
\hline
\end{tabular}




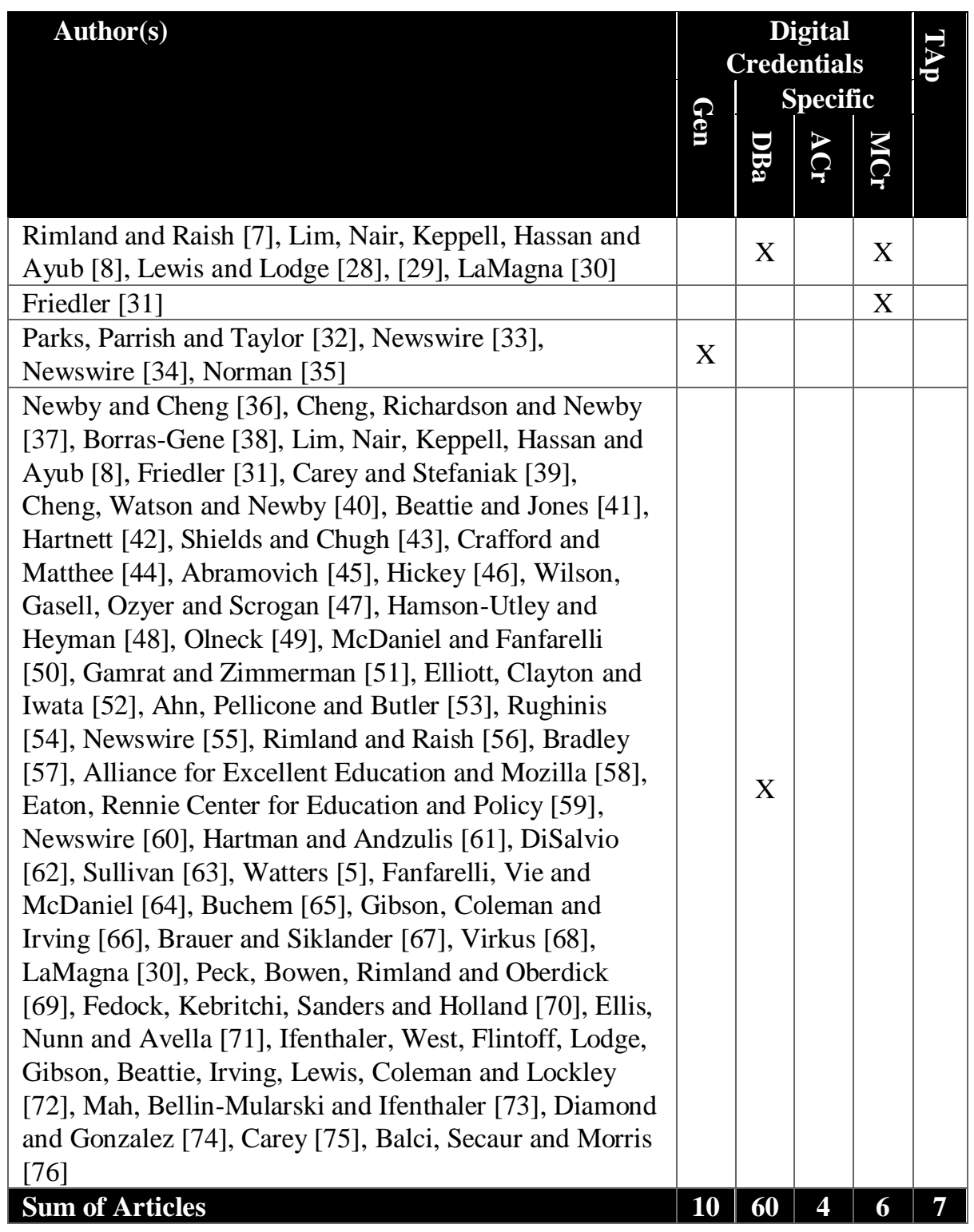

Table 1: Conceptualization of Contributions, Gen $=$ Generic, $\mathrm{DBa}=$ Digital Badges, $\mathrm{ACr}=$ Alternative Credentials, $\mathrm{MCr}=$ Micro-Credentials, $\mathrm{TAp}=$ Technical Application 


\subsection{Technical Application}

The found contributions discuss technical applications referring to blockchain implementations in the context of digital credentials, digital badges, and higher education in general. [12, 22-24] Blockchain characteristics, features, and implementation challenges of the EduCTX project are described [12, 23]. A categorization stated by [23] assigns blockchain applications into institution-centric approaches and student-centric approaches. While institution-centric applications focus on simplifying the higher education institution's processes, the student-centric category creates benefits from the 'student's perspective [23].

\subsection{Specific Digital Credentials}

\section{Digital Badges}

The usage of the specific term Digital Credentials relates to the mass of found articles in the context of Digital Badges. However, there are several different understandings of the characteristics and specifications of digital badges:

(1) as micro-credentials $[7,8,22,36,47,51,52,57,59]$,

(2) as micro-credentials and micro-learning platform [37],

(3) as a type of digital credentials [38, 58, 63],

(4) as an alternative credential $[9,36,53,62]$,

(5) as "a representation of an accomplishment, interest or affiliation that is visual, available online, and contains metadata including links that help explain the context, meaning, process, and result of an activity" [6],

(6) as a graduation certificate [31],

(7) as "a flexible format to allow educational programs to credential the learning that can sit alongside the curriculum" [41],

(8) as "an online record of achievements, tracking the 'recipient's communities of interaction that issued the badge and the work completed to get it" [62],

(9) as a nano-degree [57], and

(10) as "an online image that tells people about a new skill that 'you've learned" [64].

\section{Micro-Credentials}

Micro-credentials have been investigated in research very little so far [7, 8]. All authors synonymize micro-credentials and digital badges. According to [7], "Digital badges or micro-credentials are virtual representations of skill or knowledge, typically a granular one." [8] define micro-credentials and digital badges for being the same as the individual will get a digital badge when fulfilling the micro-credentials requirement. The research focused on possibilities to implement micro-credentials in HEIs via design principles and platform ecosystems [8]. Furthermore, potential benefits and existing vendors have been described and the importance of design choices in that context concerning the convenience and success of implementation and aspects regarding deployment and evaluation of micro-credentials [7]. 


\section{Alternative Credentials}

Alternative credentials are little discussed in research yet $[9,18,19]$. They represent learning outcomes of individuals earned through informal learning that are based on non-degree activities. These competencies refer to timely needs in professional life. [18] [9] refers to badges in the context of alternative credentials and states that they will affect the relationship between higher education and society by representing skills achieved at the workplace instead of study programs. The found literature demonstrates the relevance of alternative credentials by providing a possibility to individuals choosing not to study [18, 19]. [19] points out that a "college diploma is not the only way to the good life, the intellectual life, the cultured life, or the American dream, and it is elitist to push for an educational ecosystem in which college is the only route." Furthermore, several aspects of establishing alternative digital credentials have been discussed, like the design of icons and to represent alternative digital credentials and the represented content, implementation methods, impacts of blockchain technology on alternative digital credentials, and requirements for issuing alternative digital credentials [9].

\subsection{Generic Digital Credentials}

\section{Term Understanding of Digital Credentials}

The conceptualization of the found articles focusing on the category of digital credentials generic in education together with the forward and backward search reveals that the usage of the generic term Digital Credential also has different associations in the found literature:

(1) as academic credentials [24, 25],

(2) as "Credentials are a means by which learners can signal important information about their knowledge, skills, and aptitudes." [32]

(3) as digital badges [38, 58, 63],

(4) as micro-credentials [8], and

(5) as a "digital record of their lifelong learning achievements. Include badges, internships, boot camps, certificates, MicroMasters, and stackable combinations, as well as traditional degrees. They are shareable with employers or other institutions. Institutions can record and manage the achievements of their learners in a way that is easy, safe, and inexpensive, and minimizes the risk of identity fraud" [33].

\section{Technical Aspects of Digital Credentials}

Most publications (15) elaborate applications of digital credentials in HEIs using blockchain. News articles have a prevalence of eight, and only one publication analyzes requirements and guidelines for implementing digital credentials.

The authors focusing on blockchain applications for implementing digital credentials in education investigated several aspects:

(1) technical characteristics of the blockchain [12, 15, 24, 77-80],

(2) challenges [23, 77, 78, 81, 82],

(3) benefits $[15,24,32,77,82]$, 
(4) enablers/requirements of using the blockchain [77, 82], as well as

(5) use cases of blockchain-based digital credential implementations [11, 12, $14,15,23,24,77,79,80]$,

The technical characteristics refer to the aspects such as how to guarantee security within the blockchain, consensus mechanisms in blockchain, different architectures, scalability, and network performance of blockchain technology [78].

The news articles found in the literature give superficial information on digital credentials, referring to the usage of digital credentials in higher education and implementation projects [25-27, 33, 34, 83, 84].

One of the found articles refers to the category requirements and guidelines for implementing digital credentials in HEIs. The publication describes requirements in the context of implementing digital credentials in higher education institutions by proposing a digital credential strategy [32].

\section{Discussion}

The results of our thematic analysis confirm an increasing interest in digital credentials for HEIs [1]. The number of identified publications per year shows a significant increasing trend in publications from 2015 on.

Further, the topic is of raising interest in the area of HEIs [4] and in the field of Information Systems (IS), which underlies the increasing numbers of publications per year found through the literature search in the context of digital credentials in higher education. The proportion of source categories illustrates that the topic is new in research, as there are only a few book nominations but many conference and journal publications.

\section{Delimitation of Terms}

To our surprise, using the terms digital credentials, digital badges, micro-credentials, alternative credentials, and digital academic credentials is not precisely distinct. A more precise specification will follow. Many contributions use digital badges referring to other terms like nano-degrees [57], micro-credentials [8, 22, 36, 47], graduation certificate [31], alternative credentials [36, 53, 62] or digital credentials [38, 58, 63]. Also, there is no unique understanding and usage of the terms 'Digital Credentials' and 'Digital Badges' within the research.

The results reveal digital badges as a generic term referring to several terms within that context to cover single courses like micro-credentials, alternative credentials, or a credential for a course within a study program. Further, a combination of several courses refers to nano-degrees, graduation certificates, and digital credentials [57]. Table 2 represents the hierarchical conceptualization of digital badges in higher education institutions. 


\begin{tabular}{|c|c|c|c|c|c|c|c|}
\hline $\begin{array}{l}\text { Characte- } \\
\text { ristics }\end{array}$ & \multicolumn{7}{|c|}{ Categories } \\
\hline $\begin{array}{c}\text { Degree } \\
\text { of Coverage }\end{array}$ & \multicolumn{3}{|c|}{ Single Courses } & \multicolumn{4}{|c|}{$\begin{array}{c}\text { Combination of Several Courses, } \\
\text { Degree }\end{array}$} \\
\hline Content & $\begin{array}{c}\text { Digital } \\
\text { Creden } \\
\text {-tials }\end{array}$ & $\begin{array}{c}\text { Alter- } \\
\text { native } \\
\text { Creden- } \\
\text { tials }\end{array}$ & $\begin{array}{c}\text { Creden- } \\
\text { tials for } \\
\text { a } \\
\text { Course } \\
\text { within a } \\
\text { Study } \\
\text { Progra } \\
\text { m }\end{array}$ & $\begin{array}{c}\text { Micro- } \\
\text { Creden- } \\
\text { tials }\end{array}$ & $\begin{array}{c}\text { Micro } \\
\text { Masters } \\
\text { / Nano- } \\
\text { Degree } \\
\text { s / } \\
\text { Master } \\
\text { Track / } \\
\text { etc. }\end{array}$ & $\begin{array}{c}\text { Gradua } \\
\text {-tion } \\
\text { Certifi- } \\
\text { cate }\end{array}$ & $\begin{array}{c}\text { Record } \\
\text { of } \\
\text { Achie- } \\
\text { vement/ } \\
\text { Learnin } \\
\text { g }\end{array}$ \\
\hline $\begin{array}{c}\text { Further } \\
\text { Specification }\end{array}$ & \multicolumn{7}{|c|}{ Micro-Learning Platform } \\
\hline
\end{tabular}

Table 2: Conceptualization Digital Badges as Morphologic Box

The term digital credential is in the discussion of the literature partially used for the term digital badges $[8,58]$. The keywords of the query on the databases were Digital Credentials and Higher Education but resulted in a high number of contributions referring to digital badges (61 contributions). In conclusion, we consider that digital credentials and digital badges belong somehow together. Consequently, precision in the term of digital credentials is necessary. We understand the term digital credential from a verifier perspective regarding higher education as an umbrella term based on all other terms. The IS literature does not specify verifiable credentials in education but is used in the W3C-context [4]. Due to our focus, we do not further discuss this point.

Subsequently, we confirm the findings [33]. The degree of coverage distinguishes between single courses and a combination of achievements. Single courses refer to digital badges or micro-credentials, while the combination of achievements refers to certificates or digital academic credentials as well as MicroMasters. MicroMasters means that a student completes several MOOCs bundled for this purpose at edX for money and then spends 1-2 semesters at a cooperating university for a full Master's degree [85]. Summing up, a digital badge is always a digital credential, while a digital credential must not necessarily be a digital badge. Table 3 represents the hierarchical conceptualization of the terms in the context of digital credentials in higher education. 


\begin{tabular}{|c|c|c|c|c|c|}
\hline Characteristics & \multicolumn{5}{|c|}{ Categories } \\
\hline $\begin{array}{l}\text { Degree of } \\
\text { Coverage }\end{array}$ & \multicolumn{3}{|c|}{ Single Courses } & \multicolumn{2}{|c|}{$\begin{array}{c}\text { Combination of Lifelong Learning } \\
\text { Achievements }\end{array}$} \\
\hline Content & $\begin{array}{l}\text { Digital } \\
\text { Badges }\end{array}$ & $\begin{array}{c}\text { Micro- } \\
\text { Credentials }\end{array}$ & Certificates & $\begin{array}{c}\text { Digital } \\
\text { Academic } \\
\text { Credentials } \\
\text { or } \\
\text { Traditional } \\
\text { Degrees }\end{array}$ & $\begin{array}{c}\text { MicroMasters } \\
\text { / } \\
\text { NanoDegrees } \\
\text { / MasterTrack } \\
\text { / etc. }\end{array}$ \\
\hline
\end{tabular}

Table 3: Conceptualization Digital Credentials as Morphologic Box

In conclusion, a digital credential is a general term for digitized versions of a certificate or document representing achieved learning. A digital badge is a sub-term in that context, referring to the reveal of executed learning by specific certificate types like alternative credentials or credentials for a course within a study program. Thus, a digital badge is, in our way, understand as a distinct sign, emblem, token, or mark for a specific learning outcome within the curricula, while a digital credential can be for a whole curriculum such as a Bachelor's degree. Summarizing the study's findings, micro-credentials are mini-certifications within study programs referring to successfully participated courses, while alternative credentials are skill achievements outside the study program. Figure 2 illustrates the delimitation of the relevant terms in the context of HEI study programs.

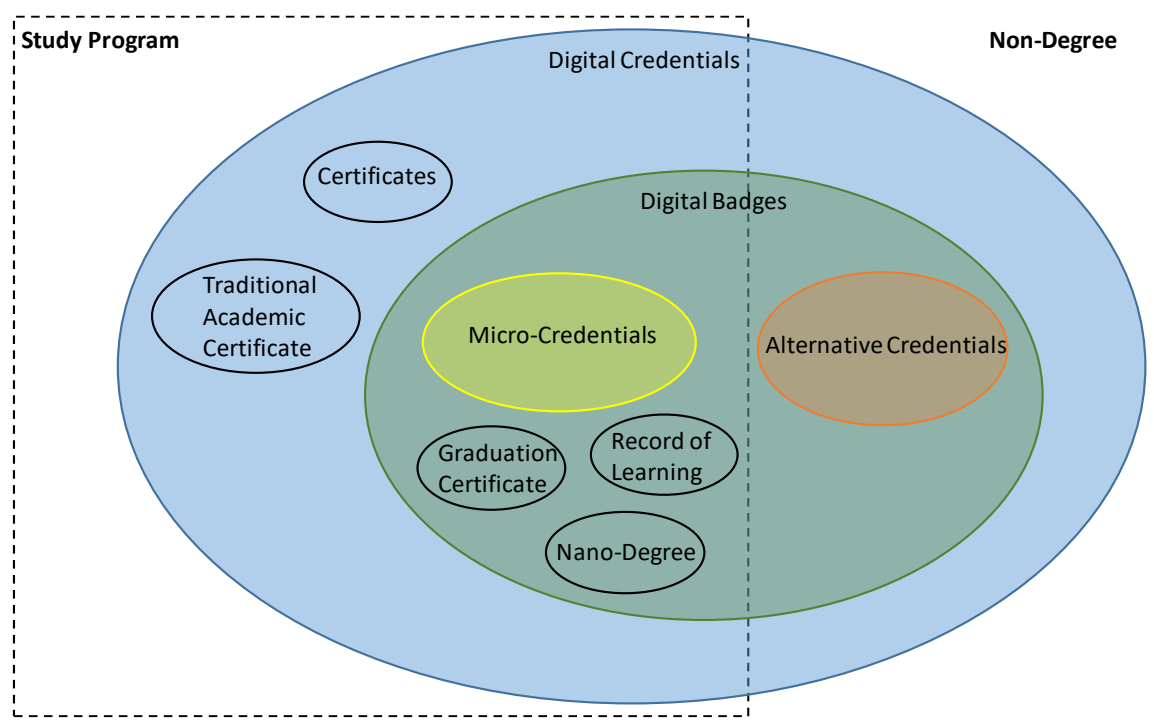

Figure 2: Delimitation of Digital Credentials, Digital Badges, Micro-Credentials, Alternative Credentials 


\section{Research Spectrum}

Moreover, the research spectrums of the research field of digital credentials in higher education vary between the different areas: research on digital badges and microcredentials covers a broad research spectrum, while the spectrum of alternative digital credentials, digital credentials, and technical applications is in comparison to these smaller. The category technical application includes studies focusing on the usage of digital credentials and their methodological application. Table 4 demonstrates the research contents of the respective areas.

\begin{tabular}{|c|c|c|c|c|c|}
\hline $\begin{array}{l}\text { Cat- } \\
\text { egory }\end{array}$ & Gen & DBa & $\mathrm{ACr}$ & $\mathrm{MCr}$ & TAp \\
\hline \multirow{5}{*}{$\begin{array}{l}\text { Con- } \\
\text { tents }\end{array}$} & \multirow{3}{*}{$\begin{array}{l}\text { Strategy } \\
\text { /Guide- } \\
\text { lines }\end{array}$} & $\begin{array}{l}\text { Implementation } \\
\text { (Open Badges) }\end{array}$ & \multirow{3}{*}{$\begin{array}{l}\text { Rele- } \\
\text { vance }\end{array}$} & Implementation & \multirow{3}{*}{$\begin{array}{l}\text { Blockchain } \\
\text { Applications }\end{array}$} \\
\hline & & Use cases & & Benefits & \\
\hline & & $\begin{array}{l}\text { Benefits (Open } \\
\text { Badges) }\end{array}$ & & $\begin{array}{l}\text { Provider } \\
\text { Overview }\end{array}$ & \\
\hline & $\begin{array}{l}\text { Block- } \\
\text { chain } \\
\text { Appli- } \\
\text { cations }\end{array}$ & $\begin{array}{l}\text { Implementation } \\
\text { Challenges }\end{array}$ & \multirow{2}{*}{$\begin{array}{l}\text { Imple- } \\
\text { menta } \\
\text {-tion }\end{array}$} & Design Options & $\begin{array}{l}\text { Blockchain } \\
\text { Applications } \\
\text { (Digital } \\
\text { Credentials) }\end{array}$ \\
\hline & $\begin{array}{l}\text { Rele- } \\
\text { vance }\end{array}$ & $\begin{array}{l}\text { Influence on } \\
\text { Learning Progress }\end{array}$ & & $\begin{array}{l}\text { Application \& } \\
\text { Evaluation }\end{array}$ & $\begin{array}{l}\text { Blockchain } \\
\text { Applications } \\
\text { (Digital Badges) }\end{array}$ \\
\hline
\end{tabular}

Table 4: Investigated Topics, Gen $=$ Generic, $\mathrm{DBa}=$ Digital Badges, $\mathrm{ACr}=$ Alternative Credentials, $\mathrm{MCr}=$ Micro-Credentials, $\mathrm{TAp}=$ Technical Application

The conceptualization of literature referring to digital credentials in education yields that many contributions refer to digital credentials applications using blockchain, and only a few references to requirements for implementing digital credentials and common knowledge within that context. As a result, a research gap exists referring to shared knowledge and digital credentials requirements.

\section{Conclusion, Limitation, and Future Research}

Our literature review shows that higher education institutions' digital credentials play a role in several IS research areas, namely blockchain technology, environmental such as ecosystems and platforms, and e-government. Ideas regarding digital credentials are still in the early stages of research. However, digital credentials in higher 
education have been examined in diverse ways, leaving its broader role ambiguous and underutilized in the IS community. We shed light on the claim of different use of names and build a fundament with a more precise definition for the distinction of digital credentials and digital badges in the IS research field.

Our findings underlie limitations such as the applied databases' regulations and, therefore, the capturing only until august 2019. There may be further contributions referring to digital credentials not covered in our literature review approach. However, our focus was the first exploration of the topic, and in the increasing new stage of the topic digital 'credential,' we will look for whitepapers to analyze this foundation in more detail. In September 2019, the W3C working group "Verifiable claims" renamed to "Verifiable credentials" [86], so in future research, we will focus on the term verifiable credentials in higher education, too.

This study provides a basis for future research on digital credentials in HEIs, as an overview of the status quo in research is still missing. We hope that this collection of studies will provoke IS researchers and strategic management researchers to step up their collaborative efforts and will provide a fruitful foundation to support the next generation of insights around digital credentials in HEIs. The future of digital credentials in higher education is already possible with today's technology; it has to be applicably discovered.

\section{References}

1. Jaakkola, H., Aramo-Immonen, H., Henno, J., Mäkelä, J.: The digitalization push in universities. In: 2016 39th International Convention on Information and Communication Technology, Electronics and Microelectronics (MIPRO), pp. 1025-1031. (2016)

2. Hanna, D.E.: Higher Education in an Era of Digital Competition: Emerging Organizational Models Journal of Asynchronous Learning Networks 2, 66-95 (1998)

3. Brands, S.: A Technical Overview of Digital Credentials. (2002)

4. Duffy, K.H., Pongratz, H., Schmidt, J.P., https://digitalcredentials.mit.edu/wpcontent/uploads/2020/02/white-paper-building-digital-credential-infrastructurefuture.pdf

5. Watters, A.: Show Me Your Badge. Campus Technology Magazine 26, 8-12 (2012)

6. Gibson, D., Ostashewski, N., Flintoff, K., Grant, S., Knight, E.: Digital badges in education. Education and Information Technologies 20, 403-410 (2015)

7. Rimland, E., Raish, V.: Micro-credentials and Digital Badges. Library Technology Reports 55, 1-34 (2019)

8. Lim, C.L., Nair, P.K., Keppell, M.J., Hassan, N., Ayub, E.: Developing a Framework for the University-Wide Implementation of Micro-Credentials and Digital Badges: A Case Study From a Malaysian Private University. In: 2018 IEEE 4th International Conference on Computer and Communications (ICCC), pp. 1715-1719. (2018)

9. Matkin, G.W.: Alternative Digital Credentials: An Imperative of Higher Education. Center for Studies in Higher Education, University of California, Berkeley (2018)

10. Mercury, M.T., Schmidt, K.J.: Generation, Management, and Tracking of Digital Credentials. In: Office, U.S.P.a.T. (ed.), vol. US 2017/0279614 A1, pp. 16, United States (2017) 
11. Colle, C., De Capitani, A., Lindroos, K., Maris, A., Virgl, T., Zylka, K.: Gradbase Decentralised academic record verification using the Bitcoin blockchain. Imperial College London (2015)

12. Hölbl, M., Kamisalić, A., Turkanović, M., Kompara, M., Podgorelec, B., Herićko, M.: EduCTX: An Ecosystem for Managing Digital Micro-Credentials. In: 2018 28th EAEEIE Annual Conference (EAEEIE), pp. 1-9. (2018)

13. Hope, J.: Issue secure digital credentials using technology behind bitcoin. The Successful Registrar 17, 1-4 (2018)

14. Sharples, M., Domingue, J.: The Blockchain and Kudos: A Distributed System for Educational Record, Reputation and Reward. pp. 490-496. Springer International Publishing, (2016)

15. Turkanović, M., Hölbl, M., Košič, K., Heričko, M., Kamišalić, A.: EduCTX: A Blockchain-Based Higher Education Credit Platform. IEEE Access 6, 5112-5127 (2018)

16. Webster, J., Watson, R.T.: Analyzing the Past to Prepare for the Future: Writing a Literature Review. MIS Quarterly 26, xiii-xxiii (2002)

17. Brocke, J.v., Simons, A., Niehaves, B., Riemer, K., Plattfaut, R., Cleven, A.: Reconstructing the giant: On the importance of rigour in documenting the literature search process. In: ECIS. (2009)

18. AACSB: The Disruptive Power Of Digital Credentials. BizEd 18, 11-11 (2019)

19. Bull, B.: Why Colleges Should Support Alternative Credentials. Chronicle of Higher Education 62, 12-12 (2015)

20. Farmer, T., West, R.E.: Opportunities and Challenges with Digital Open Badges. Educational Technology 56, 45-48 (2016)

21. Swan, M.: Chapter Five - Blockchain for Business: Next-Generation Enterprise Artificial Intelligence Systems. In: Raj, P., Deka, G.C. (eds.) Advances in Computers, vol. 111, pp. 121-162. Elsevier (2018)

22. Jirgensons, M., Kapenieks, J.: Blockchain and the Future of Digital Learning Credential Assessment and Management. Journal of Teacher Education for Sustainability 20, 145$156(2018)$

23. Kamišalić, A., Turkanović, M., Mrdović, S., Heričko, M.: A Preliminary Review of Blockchain-Based Solutions in Higher Education. vol. 1011, pp. 114-124 (2019)

24. Arenas, R., Fernandez, P.: CredenceLedger: A Permissioned Blockchain for Verifiable Academic Credentials. In: 2018 IEEE International Conference on Engineering, Technology and Innovation (ICE/ITMC), pp. 1-6. (2018)

25. Newswire, P.R.: ODEM Issues Blockchain Certificates for Canadian Polytechnic. ODEM.IO-Certificates. (2018)

26. Newswire, P.R.: Using Blockchain, New Mexico Community College Becomes First Community College to Issue Student-Owned Digital Diplomas. CNMBlockchainDiploma. (2017)

27. Connolly, B.: Credentials the new 'currency for careers'. CIO (13284045) 1-1 (2015)

28. Lewis, M.J., Lodge, J.M.: Keep calm and credential on: Linking learning, life and work practices in a complex world. Foundation of Digital Badges and Micro-Credentials: Demonstrating and Recognizing Knowledge and Competencies, pp. 41-54 (2016)

29. Micro-credentials and Digital Badges. Library Technology Reports 55, 1-34 (2019)

30. LaMagna, M.: Placing Digital Badges and Micro-Credentials in Context. Journal of Electronic Resources Librarianship 29, 206-210 (2017)

31. Friedler, A.: Teachers Training Micro-Learning Innovative Model: Opportunities and Challenges. In: 2018 Learning With MOOCS, LWMOOCS 2018, pp. 63-65. (2018) 
32. Parks, R., Parrish, J., Taylor, A.: Creating a Digital Credential Strategy. College and University 93, 71-76 (2018)

33. Newswire, P.R.: Nine Universities Team Up To Create Global Infrastructure For Digital Academic Credentials. MIT-infrastructure. (2019)

34. Newswire, P.R.: Popular Digital Credentialing Platform Raises \$11.1 Million. CREDLY-funding. (2019)

35. Norman, M.: Accessing services with client digital certificates: A short report from the DCOCE project. New Review of Information Networking 10, 193-207 (2004)

36. Newby, T.J., Cheng, Z.: Instructional digital badges: effective learning tools. Educational Technology Research and Development (2019)

37. Cheng, Z., Richardson, J.C., Newby, T.J.: Using digital badges as goal-setting facilitators: a multiple case study. Journal of Computing in Higher Education (2019)

38. Borras-Gene, O.: Use of digital badges for training in digital skills within higher education. (2018)

39. Carey, K., Stefaniak, J.: An exploration of the utility of digital badging in higher education settings. Educational Technology Research and Development 66, 1211-1229 (2018)

40. Cheng, Z., Watson, S.L., Newby, T.J.: Goal Setting and Open Digital Badges in Higher Education. TechTrends 62, 190-196 (2018)

41. Beattie, S., Jones, W.: The momentum program: Digital badges for law students. pp. 4552. (2018)

42. Hartnett, M.: Digital badges - What is the state of play within the New Zealand Higher Education sector? In: ASCILITE 2018 Conference Proceedings, pp. 390-395. (Year)

43. Shields, R., Chugh, R.: Digital badges - rewards for learning? Education and Information Technologies 22, 1817-1824 (2017)

44. Crafford, R., Matthee, M.: Implementing open badges for recognition of learning achievements in South African organisations. (2016)

45. Abramovich, S.: Understanding digital badges in higher education through assessment. On the Horizon 24, 126-131 (2016)

46. Hickey, D.T.: Competency-Based Digital Badges and Credentials: Cautions and Potential Solutions From the Field. In: ICLS. (2016)

47. Wilson, B.G., Gasell, C., Ozyer, A., Scrogan, L.: Adopting digital badges in higher education: Scoping the territory. Foundation of Digital Badges and Micro-Credentials: Demonstrating and Recognizing Knowledge and Competencies, pp. 163-177 (2016)

48. Hamson-Utley, J., Heyman, E.: Implementing a badging system faculty development. Foundation of Digital Badges and Micro-Credentials: Demonstrating and Recognizing Knowledge and Competencies, pp. 237-258 (2016)

49. Olneck, M.R.: Whom will digital badges empower? Sociological perspectives on digital badges. pp. 5-11. (2015)

50. McDaniel, R., Fanfarelli, J.R.: How to design experimental research studies around digital badges. pp. 30-35. (2015)

51. Gamrat, C., Zimmerman, H.T.: An online badging system supporting 'educators' STEM learning. In: CEUR Workshop, pp. 12-23. (2015)

52. Elliott, R., Clayton, J., Iwata, J.: Exploring the use of micro-credentialing and digital badges in learning environments to encourage motivation to learn and achieve. pp. 703707. (2014)

53. Ahn, J., Pellicone, A., Butler, B.S.: Open badges for education: What are the implications at the intersection of open systems and badging? Research in Learning Technology 22, (2014) 
54. Rughinis, R.: Talkative objects in need of interpretation. re-thinking digital badges in education. CHI ''13 Extended Abstracts on Human Factors in Computing Systems, pp. 2099-2108. ACM, Paris, France (2013)

55. Newswire, P.R.: Blackboard Partners with Mozilla to Support Use of Digital Badges. Blackboard-\&-Mozilla. (2013)

56. Rimland, E., Raish, V.: Chapter 2: Overview, Definitions, and Benefits. Library Technology Reports 55, 7-8 (2019)

57. Bradley, P.: Digital Badging Is Growing, but Employers Remain Wary. Community College Week, vol. 28, pp. 39-40 (2016)

58. Alliance for Excellent Education, Mozilla, F.: Expanding Education and Workforce Opportunities through Digital Badges. Alliance for Excellent Education (2013)

59. Eaton, A., Rennie Center for Education, R., Policy: Expanding the Boundaries of Education: Two 'Cities' Efforts to Credential Real-World Skills through Digital Badges. Rennie Center for Education Research \& Policy (2019)

60. Newswire, P.R.: IACET Announces Partnership with Badgr for the Open Digital Badge Experience Course. IACET-Badgr-course. (2019)

61. Hartman, K.B., Andzulis, J.: Industry-Based Certificates: Student Perceptions of Benefits. Research in Higher Education Journal 36, (2019)

62. DiSalvio, P.: New Pathways to Credentialing: The Digital Badge. New England Journal of Higher Education (2016)

63. Sullivan, A.L.: Open Badges and Student Motivation: A Study of Their Relationship to Student Assessment Scores. ProQuest LLC (2018)

64. Fanfarelli, J., Vie, S., McDaniel, R.: Understanding digital badges through feedback, reward, and narrative: a multidisciplinary approach to building better badges in social environments. Commun. Des. Q. Rev 3, 56-60 (2015)

65. Buchem, I.: Design patterns for digital competency credentials based on open badges in the context of virtual mobility In: DeLFI Workshops 2018. (2018)

66. Gibson, D., Coleman, K., Irving, L.: Badging digital pathways of learning. In: ASCILITE- Australasian Society for Computers in Learning and Tertiary Education, Conference Proceedings 2019, pp. 440-444. (2019)

67. Brauer, S., Siklander, P.: Competence-based assessment and digital badging as guidance in vocational teacher education. pp. 191-196. (2019)

68. Virkus, S.: The use of Open Badges in library and information science education in Estonia. Education for Information 35, 155-172 (2019)

69. Peck, K., Bowen, K., Rimland, E., Oberdick, J.: Badging as micro-credentialing in formal education and informal education. Digital Badges in Education: Trends, Issues, and Cases, pp. 82-92 (2016)

70. Fedock, B., Kebritchi, M., Sanders, R., Holland, A.: Digital badges and microcredentials: Digital age classroom practices, design strategies, and issues. Foundation of Digital Badges and Micro-Credentials: Demonstrating and Recognizing Knowledge and Competencies, pp. 273-286 (2016)

71. Ellis, L.E., Nunn, S.G., Avella, J.T.: Digital badges and micro-credentials: Historical overview, motivational aspects, issues, and challenges. Foundation of Digital Badges and Micro-Credentials: Demonstrating and Recognizing Knowledge and Competencies, pp. 3-21 (2016)

72. Ifenthaler, D., West, D., Flintoff, K., Lodge, J., Gibson, D., Beattie, S., Irving, L., Lewis, M., Coleman, K., Lockley, A.: Moving forward with digital badges. In: ASCILITE 2016, pp. 275-277. (2016) 
73. Mah, D.K., Bellin-Mularski, N., Ifenthaler, D.: Foundation of digital badges and microcredentials: Demonstrating and recognizing knowledge and competencies (2016)

74. Diamond, J., Gonzalez, P.C.: Digital badges for professional development: Teachers' perceptions of the value of a new credentialing currency. Foundation of Digital Badges and Micro-Credentials: Demonstrating and Recognizing Knowledge and Competencies, pp. 391-409 (2016)

75. Carey, K.: Show Me Your Badge. New York Times 162, 28 (2012)

76. Balci, S., Secaur, J.M., Morris, B.J.: The Effectiveness of Gamification Tools in Enhancing Academic Performance and Motivation of Students in Fully vs. Partially Gamified Grading System of Online Classes. Proceedings of the Technology, Mind, and Society, pp. 1-1. ACM, Washington, DC, USA (2018)

77. Grech, A., Camilleri, A.F.: Blockchain in Education. Luxembourg : Publications Office of the European Union 2017 (2017)

78. Kazakzeh, S., Ayoubi, E., Muslmani, B.K., Qasaimeh, M., Al-Fayoumi, M.: Framework for Blockchain Deployment: The Case of Educational Systems. In: 2019 2nd International Conference on new Trends in Computing Sciences (ICTCS), pp. 1-9. (2019)

79. Oyelere, S., Tomczyk, Ł., Bouali, N., Joseph, A.F.: Blockchain technology and gamification - conditions and opportunities for education. Proceedings of the 8th International Adult Education Conference, Prague (2019)

80. Yeasmin, S., Baig, A.: Unblocking the Potential of Blockchain. In: 2019 International Conference on Electrical and Computing Technologies and Applications (ICECTA), pp. 1-5. (2019)

81. Haugsbakken, H., Langseth, I.: The Blockchain Challenge for Higher Education Institutions. European Journal of Education 2, 41-46 (2019)

82. Alammary, A., Alhazmi, S., Almasri, M., Gillani, S.: Blockchain-Based Applications in Education: A Systematic Review. . Applied Sciences 9, (2019)

83. Bitcoin Magazine, https://www.nasdaq.com/articles/cardano-blockchains-first-use-caseproof-university-diplomas-greece-2018-01-02

84. Campus Technology, https://campustechnology.com/articles/2018/06/11/southern-newhampshire-u-issues-blockchain-credentials-to-college-for-america-grads.aspx

85. edx: MicroMasters Trademark Guidelines. edx (2019)

86. W3C, https://www.w3.org/2017/vc/WG/ 